\title{
PENGARUH PENILAIAN KETERAMPILAN MATA PELAJARAN PPKn DALAM KURIKULUM 2013 TERHADAP PEMBINAAN TANGGUNGJAWAB WARGA NEGARA (CIVIC RESPONSIBILITY) DI SMK NEGERI SE-KOTA B ANDUNG
}

\author{
Oleh: Cahyono* dan Aim Abdul Karim*
}

\begin{abstract}
Skill assessment, which is called performance assessment, is part of assessment domains in curriculum 2013. In PPKn subject, skills assessment can assistlearners to foster their attitude of solidarity, democratic, and responsible through practice assignment, project, and portfolio technique. The purpose of this research is to know how the effect of the implementation of skills assessment based on curriculum 2013 in PPKn subject toward the educationof civic responsibility on the learners. The basic theory is permendikbud No. 104 (2014) about the assessment standards and assessment theory Widoyoko (2014), the theory of civic responsibility Branson (1999). The approach used is quantitative research with survey method. A population is of 2380 students. Technique used is random sampling as many as 336 respondents. Data collection used is questionnaire, using correlation and regression analysis. Based on data analysis, influence planning $\left(X_{1}\right)$ and implementation skills assessment $\left(\mathrm{X}_{2}\right)$ on the education of civic responsibility $(Y)$ has positive effect amounting to $21,47 \%$.
\end{abstract}

Key Words: Curriculum 2013, skills assessment, civic responsibility.

\section{PENDAHULUAN}

Generasi bangsa Indonesia saat ini perlu dibina dan disiapkan guna menyongsong Indonesia yang maju, mandiri, mapan, dan mampu berkompetitif dengan bangsa lain. Hal ini sesuai dengan apa yang disampaikan oleh Budimansyah (2010, hlm. 2), yang menyatakan bahwa oleh karena itu, pembinaan terhadap generasi muda menjadi warga negara yang baik menjadi perhatian utama, tidak ada tugas yang lebih penting dari pengembangan warga negara yang bertanggungjawab, efktif dan terdidik.

Hal tersebut jelas bahwa pendidikan dan pembinaan generasi muda sangat penting dalam mewujudkan cita-cita pendidikan guna menyiapkan generasi emas di masa yang akan datang. Untuk merealisasikan hal tersebut maka dibuatkan kurikulum sebagai rancangan pendidikan. Kurikulum merupakan pedoman dan racangan pelaksanaan pendidikan yang dijadikan sebagai penuntun dan pegangan dalam pelaksanaan sistem pendidikan.

\footnotetext{
* Mahasiswa Departemen Pendidikan Kewarganegaraan Sekolah Pascasarjana Universitas Pendidikan Indonesia.Email: yonjun85@gmail.com

-Dosen Departemen Pendidikan Kewarganegaraan Sekolah Pascasrajana Universitas Pendidikan Indonesia
} 
Dalam kurikulum 2013 terdapat keseimbangan antara soft skill dan hard skill yakni aspek keseimbangan antara keterampilan dasar peserta didik berupa penanaman sikap dan karakter atau kepribadian yang diwujudkan dengan sikap-sikap yang salah satunya sikap tanggungjawab terhadap apa yang dikerjakan, dilakukan dan tanggungjawab terhadap tugas dan kedudukannya dalam masyarakat. Kurikulum 2013 telah mengarahkan semua mata pelajaran untuk mewujudkan hal-hal tersebut. Penanaman sikap, kepribadian, dan tanggungjawab peserta didik telah diarahkan dalam setiap mata pelajaran dari semua jenjang pendidikan.

Salah satu mata pelajaran yang sangat erat dengan aspek penanaman sikap dan kepribadian serta sikap tanggungjawab adalah mata pelajaran PPKn. Selain itu, mata pelajaran Pendidikan Pancasila dan Kewarganegaraan (PPKn) yang dipersiapkan dalam menghadapi persaingan hidup di masyarakat dan umunya persaingan global. Hal tersebut senada dengan apa yang menjadi tujuan Pendidikan Kewarganegaraan menurut Badan Standar Nasional Pendidikan (BSNP), yaitu sebagai berikut:

1. Berpikir secara kritis, rasional, dan kreatif dalam menanggapi isu kewarganegaraan.

2. Berpartisipasi secara aktif dan bertanggung jawab, dan bertindak secara cerdas dalam kegiatan bermasyarakat, berbangsa, dan bernegara.

3. Berkembang secara positif dan demokratis untuk membentuk diri berdasarkan karakterkarakter masyarakat Indonesia agar dapat hidup bersama bangsa-bangsa lainnya.

4. Berinteraksi dengan bangsa-bangsa lain dalam percaturan dunia secara lansung dengan memanfaatkan teknologi informasi dan komunikasi.

Tujuan pembelajaran PPKn yang menitikberatkan pada aspek penanaman sikap dan kepribadian peserta didik agar menjadi warga negara yang baik, yakni baik kepada Tuhannya, baik kepada negaranya dan baik terhadap sesamanya dengan mampu menunjukan salah satu sikap tanggungjawab sebagai warga negara (civicresponsibility) dan memiliki keterampilan warga negara yang baik (civic skill) dalam bentuk keterampilan partisipasi dalam proses pengambilan keputusan (partisipation skill). Hal ini sesuai dengan pendapat Maftuh dan Sapriya (2005, hlm. 320), menyatakan bahwa tujuan negara mengembangkan Pendidikan Kewarganegaraan $(\mathrm{PKn})$ adalah ....agar setiap warga negara menjadi warga negara yang baik (to be good citizens), yakni warga yang memiliki kecerdasan (Civic Intelligence) baik intelektual, emosional, sosial, maupun spiritual; memiliki rasa bangga dan tanggung jawab (Civic Responsibility); dan mampu berpartisipasi dalam kehidupan bermasyarakat dan bernegara (Participation skill) agar tumbuh rasa kebangsaan dan cinta tanah air. 
Selain aspek pembelajaran PPKn yang menekankan pada aspek penanaman sikap dan kepribadian, penilaian mata pelajaran PPKn pun sangat besar kontribusinya dalam menanamkan dan mengarahkan pembentukan sikap dan kepribadian para peserta didik yang sesuai dengan jiwa dan kepribadian bangsa, yakni pribadi yang sesuai dengan nilai-nilai budaya bangsa, pancasila dan konstitusi Negara. Adapun penilaian mata pelajaran PPKn dalam kurikulum 2013 yang terdiri dari penilaian sikap sosial dan spiritual, penilaian pengetahun, dan penilaian keterampilan, jenis-jenis penilaian tersebut akan mampu memicu terbentuknya kepribadian dan sikap peserta didik yang sesuai dengan tuntutan dan tujuan PPKn yakni menjadi warga Negara yang baik, yang memiliki kepribadian dan akhlak yang baik, demokratis, dan tanggungjawab. Dalam penilaian mata pelajaran PPKn kurikulum 2013, semua aspek penilaian dan indikator penilaian mengarahkan pada penanaman karakter dan kepribadian peserta didik.

Aspek penilaian sangat dibutuhkan dalam setiap pembelajaran, karena penilaian merupakan komponen pendidikan yang tidak bisa dilepaskan dalam setiap pembelajaran. Berdasarkan Permendikbud No. 104 tahun 2014, tentang standar penilaian, yang berbunyi: Penilaian merupakan adalah proses pengumpulan informasi/bukti tentang capaian pembelajaran peserta didik dalam kompetensi sikap spiritual dan sikap sosial, kompetensi pengetahuan, dan kompetensi keterampilan yang dilakukan secara terencana dan sistematis, selama dan setelah proses pembelajaran.

Dari definisi di atas, bisa dikatan bahwa penilaian merupakan faktor yang tidak bisa dipisahkan dalam pelaksanaan pendidikan. Hal ini senada dengan Stefani 1998; Orsmond \& Taras 2001; Patri 2002; Alderson 2005; Kato 2009; Buler \& Lee 2010; Abbaszadeh 2012; Cheng \& Curtis 2012 dalam Goudarz Alibakhshi (2014, hlm. 9-17), yang menyatakan bahwa Assessment is an integral part of every educational system through which learners' achievements are evaluated on the basis of the material taught (Penilaian merupakan bagian integral dari setiap sistem pendidikan di mana prestasi peserta didik dievaluasi dasar materi yang diajarkan). Hal ini senada dengan pendapat Widoyoko (2014 hlm. 4), yang menyatakan bahwa; Penilaian dapat diartikan sebagai kegiatan menafsirkan atau memaknai data hasil suatu pengukuran berdasarkan kriteria atau standar maupun autran-aturan tertentu, dengan kata lain penilaian diartikan sebagai pemberian makna atau ketetapan kualitas hasil suatu pengukuran dengan cara membandingkan data hasil pengukuran dengan kriteria atau standar tentntu.

Penilaian mata pelajaran PPKn dalam kurikulum 2013 merupakan salah satu cara untuk mengukur pencapaian kompetensi siswa, salah satunya adalah kompetensi sikap yakni 
sikap dan karakter yang baik. Salah satunya diwujudkan dalam bentuk sikap tanggungjawab akan fungsi dan kedudukannya dalam lingkungan rumah, sekolah, masyarakat, bangsa dan Negara. Salah satu penilaian mata pelajaran PPKn dalam kurikulum 2013 yang mampu mengarahkan terhadap pembinaan tanggungjawab, yakni penilaian keterampilan. Penilaian keterampilan yang terdiri dari jenis penilaian praktik, projek, produk dan portofolio akan melatih para peserta didik untuk belajar bertanggungjawab terhadap tugas-tugasnya, fungsi dan kedudukannya dalam kegiatan kelompok. Hal tersebut akan melatih para peserta didik agar mampu memiliki jiwa tanggungjawab terhadap pekerjaannya masing-masing, tugas dan peranannya masing-masing dalam kegiatan pembelajaran.

Melalui penilaian keterampilan dengan menggunakan jenis penilaian praktek, projek, dan portofolio, peserta didik diarahkan dan dibentuk menjadi sosok yang memiliki karakter dan kepribadian yang bertanggungjawab. Hal ini dilakukan melalui pembiasaan ketika para peserta didik mengerjakan tugas-tugas praktek, projek dan tugas portofolio dalam kompetensi keterampilan tersebut. Melalui penilaian keterampilan ini peserta didik akan memiliki jiwa tanggungjawab yang tinggi terhadap penyelesaian tugas-tugasnya, perananannya dalam kelompoknya, dan proses keaslian tugas-tugas yang mereka kerjakan. Selain itu penilaian keterampilan akan menanamkan sikap tanggungjawab peserta didik dalam mempertanggungjawabkan tugas-tugas yang telah mereka selesaikan.

Penilaian tersebut merupakan salah satu penilaian yang bersifat kontekstual dan factual untuk membuktikan dan menguji tingkat disiplin, ketelitian, kecermatan, kekompakan, solidaritas dan rasa tanggungjawab antar peserta didik dalam menyelesaikan tugas-tugas yang ada dalam kompetensi keterampilan tersebut. Selain itu penilaian keterampilan inipun akan menumbuhkan sikap terampil peserta didik dalam berkomunikasi, bersosialisasi, dan terampil dalam membuat dan mengembangkan karya-karya dan tuagstugas praktek, proyek dan portofolio. Keterampilan komunikasi dan sosialisasi serta menyampaikan ide dan gagasannya dalam kegiatan kelompok pada proses pengerjaan tugas praktek, proyek, produk dan portofolio akan membantu peserta didik dalam menumbuhkan jiwa terampil dan tanggungjawab terhadap apa yang mereka sampaikan, lakukan dan kerjakan.

Namun dalam prakteknya, pelaksanaan kurikulum 2013 khususnya pada aspek penilaiannya masih belum dilakukan secara optimal oleh guru-guru di sekolah, sekalipun di sekolah-sekolah percontohan yang sudah satu tahun lebih awal melaksanakan kurikulum 2013. Hal tersebut disebabkan terlalu banyaknya aspek yang harus dinilai oleh seorang guru terhadap peserta didik, sedangkan waktu untuk melaksanakan penilaiannya sangat sempit. 
Sehingga nilai yang diberikan guru terhadap para peserta didik merupakan nilai yang kurang objektif. Hal tersebut menyebabkan beberapa kompetensi siswa dalam kurikulum 2013 kurang tercapai secara maksimal. Salah satunya mengenai pelaksanaan penilaian keterampilan.

Selain masalah di atas, guru-guru juga masih banyak yang belum menguasai dan mengerti tentang cara pelaksanaan penilaian keterampilan dalam kurikulum 2013. Sehingga dari masalah tersebut, dikawatirkan akan terjadinya ketimpangan antara tujuan dalam kurikulum 2013 dengan realita pelaksanaan kurikulum 2013 khususnya pada aspek penilaian keterampilan. Sedangkan aspek penilaian keterampilan merupakan aspek yang sangat penting dalam proses pendidikan, dan pembinaan sikap dan kepribadian para pesarta didik agar kelak menjadi siswa yang memiliki sikap tanggungjawab sebagai warga Negara, baik terhadap dirinya, keluarganya, masyarakatnya, bangsa dan negaranya. Untuk mencapai hal terebut dibutuhkan peran dan fungsi guru sebagai salah satu penilai dalam pelaksanaan penilaian keterampilan. Hal tersebut senada dengan Borhan (1998), menyatakan bahwa: Guru memainkan peranan penting dalam mengesan kebolehan, kemajuan dan pencapaian murid. Guru menentukan hasil pembelajaran yang hendak dinilai, merancang dan membina instrumen penilaian, menganalisis maklumat penilaian, melapor dan membuat tindakan susulan.

Salah satu tugas praktek yang bisa diterapkan dalam penilaian keterampilan ini adalah praktek simulasi pemilu, dan praktek penegakkan HAM melalui simulasi atau diskusi, di mana materi tersebut merupakan materi yang ada pada kelas XI semester 3. Melalui praktek simulasi pemilu dan praktek penegakkan HAM dalam kegiatan diskusi, peserta didik akan dibentuk jiwa terampil dalam menyampaikan ide dan gagasannya, terampil dalam berargumentasi, terampil dalam bersosialiasi, terampil dalam mempengaruhi dan memikat orang lain untuk mengikuti apa yang keinginannya, dan memiliki jiwa tanggungjawab terhadap apa yang mereka harus lakukan dan tanggungjawab atas apa yang mereka telah lakukan.

Penilaian keterampilan mata pelajaran PPKn lainnya adalah penilaian projek dan penilaian portofolio. Di mana melalui penilaian ini pembentukan jiwa tanggungjawabnya melalui proses penyelesaian tugas-tugasnya yang dilakukan baik secara individu maupun secara kelompok. Tugas projek merupakan salah satu tugas dalam penilaian keterampilan yang harus dikerjakan oleh para peserta didik dengan batasan waktu tertentu. Sehingga para peserta akan dibentuk jiwa terampil dalam mengatur waktunya, terampil dalam membagibagi tugas masing-masing kelompoknya serta akan terbentuk jiwa tanggungjawab terhadap 
tugas dan fungsi masing-masing dalam proses penyelesaian tugas projek tersebut. Salah satu tugas projek yang bisa diberikan adalah pembuatan video pelanggaran HAM. Melalui tugas ini peserta didik akan dilatih untuk mampu berkomitmen tinggi terhadap kelompoknya, dan terhadap perananya. Sehingga dengan kegiatan pembuatan video pelanggarna HAM ini akan terbentuk jiwa tanggungjawab di antara para peserta didik.

Civic responsibility atau tanggungjawab warga Negara merupakan salah satu bentuk karakter atau watak warga Negara (civic disposition). Tanggungjawab warga Negara harus dimiliki oleh setiap pribadi warga Negara. Untuk mewujudkan hal tersebut, maka karakter atau watak tanggungjawab warga Negara ini harus dilatih, dan ditanamkan sejak dini kepada masyarakat, khususnya kepada para peserta didik di tingkat SMA/SMK. Penanaman sikap tanggungjawab ini membutuhkan waktu dan proses yang tidak sebentar. Untuk itu proses penanaman dan pembentukan sikap tanggungjawab ini harus dilatih melalui berbagai cara, salah satunya melalui pembiasaan untuk mengerjakan tugas-tugas sekolahnya baik tugas individu maupun tugas kelompoknya.

Tanggung jawab menurut kamus umum Bahasa Indonesia adalah keadaan wajib menanggung segala sesuatunya. Sehingga bertanggung jawab menurut kamus umum bahasa Indonesia adalah berkewajiban menanggung, memikul jawab, menanggung segala sesuatunya, atau memberikan jawab dan menaggung akibatnya. Tanggung jawab adalah kesadaran manusia akan tingkah laku atau perbuatannya yang disengaja maupun yang tidak disengaja. Hal ini sesuai dengan apa yang disampaikan oleh Branson (1999, hlm. 23-25), yang menyatakan bahwa Kesadaran secara pribadi untuk bertanggungjawab sesuai ketentuan, bukan karena keterpaksaan atau pengawasan dari luar, menerima tanggungjawab akan konsekuensi dan tindakan yang diperbuat dan memenuhi kewajiban moral dan legal sebagai anggota masyarakat demokratis.

Pendidikan formal yakni pendidikan di sekolah, yang saat ini sudah diberi arahan melalui kurikulum 2013 yang telah diterapkan di semua jenjang pendidikan di Indonesia. Dalam kurikulum 2013 telah diarahkan untuk penanaman sikap, watak, karakter dan akhlak peserta didik. Yang salah satunya adalah memiliki sikap tanggungjawab. Tanggungjawab warga Negara saat ini sangat dibutuhkan, mengingat banyaknya warga Negara yang mampu berbuat namun tidak mampu untuk mempertanggungjawab perbuatannya tersebut. Sehingga munculah berbagai konflik dalam kehidupan pribadinya, masyarakat, bangsa dan Negara.

Untuk itulah pembentukan sikap tanggungjawab warga Negara ini harus ditanamkan sejak dini, salah satunya kepada para peserta didik. Kurikulum 2013 sudah memberikan jalan untuk itu. Salah satunya melalui penilaian keterampilan yang menekankan pada aspek 
penilaian kinerja. Dengan penilaian kinerja ini para peserta didik akan dibiasakan untuk berbuat, bertindak dan berperilaku sesuai dengan tuntutan dan criteria penilaian yang ada sebagai pedoman penilaian keterampilan tersebut.

Sikap tanggungjawab harus dimiliki oleh setiap warga Negara. Baik tanggungjawab terhadap dirinya, keluarganya, masyarkat, bangsa dan negaranya serta terhadap agama dan Tuhannya. Bentuk dan perwujudan sikap tanggungjawab ini dapat kita lihat dalam kehidupan sehari-harinya. Encan (2013) menuliskan contoh bentuk dan perwujudan warga Negara yang mencerminkan sikap dan perilaku tanggungjawab terhadap bangsa, dan Negara adalah sebagai berikut:

1. Memahami dan mengamalkan ideologi bangsa kita, yakni ideologi pancasila dalam kehidupan sehari-hari dari semua bidang kehidupan, baik bidang ekonomi, sosial, budaya, politik dan keamanan.

2. Menjaga dan memelihara nama baik bangsa di mata internasional, dan selalu menjaga harkat dan marbat bangsa yang merdeka, berdaulat, beperadaban dan bermartabat

3. Menjaga kesatuan dan persatuan bangsa dengan menghindari perilaku yang diskriminatif

4. Membina solidaritas sosial sebagai sesame anggota warga Negara Indonesia

5. Meningkatkan wawsan kebangsaan agar senantiasa meningkatkan rasa kebangsaan, paham kebangsaan, semangat kebangsaan pada setiap diri warga Negara

Sedangkann wujud sikap tanggung jawabwarga negara (citizen responsibility/civic responsibilities) menurut CCE (1994, hlm. 37) diataranya dapat dicontohkan sebagai berikut:

1. Melaksanakan aturan hukum;

2. Menghargai hak orang lain;

3. Memiliki informasi dan perhatian terhadap kebutuhan-kebutuhan masyarakatnya;

4. Melakukan kontrol terhadap para pemimpin yang dipilihnya dalam melaksanakan tugas - tugasnya;

5. Melakukan komunikasi dengan para wakil di sekolah, pemerintah lokal, pemerintah nasional;

6. Memberikan suara dalam suatu pemilihan;

7. Membayar pajak;

8. Menjadi saksi di pengadilan;

9. Bersedia untuk mengikuti wajib militer, dsb. 
Berdasarkan pemaparan di atas, sikap tanggungjawab warga Negara ini memang sangat dibutuhkan untuk pembentukan kehidupan Negara yang aman tentram, adil makmur sejahtra dan demokratis. Sikap tanggungjawab warga Negara ini tidak muncul begitu saja dalam diri setiap warga Negara, melainkan harus dilatih dan dibentuk dengan cara dan system yang benar dan ditanamkan sejak dini. Salah satu cara untuk membentuk sikap tanggungjawab warga Negara ini tersebut adalah melalui jalur pendidikan di sekolah.

Dalam buku guru PPKn kelas XI (2013, hlm. 14) terdapat format penilaian keterampilan mata pelajaran PPKn yang dapat diringkas bahwa sikap yang mencerminkan tanggungjawab, secara rinci dapat dilihat dari aktivitas peserta didik sebagai berikut:

1. Taat dan patuh pada ajaran agama yang dianutnya

2. Datang dan pulang sekolah tepat waktu

3. Selalu mentaati segala peraturan sekolah, rumah, masyarakat, dan negaranya

4. Membantu temannya yang kesusahan

5. Taat dan hormat pada guru, dan orang tua

6. Belajar dengan baik dan tidak pernah bolos sekolah

7. Selalu mengerjakan tugas sekolah dengan tepat waktu

8. Aktiv dalam kegiatan diskusi kelompok

9. Menghormati dan menghargai pendapat orang lain dan tidak pernah memaksakan kehendaknya kepada orang lain

10. Mengerjakan tugas-tugasnya dengan teliti, cermat, kreatif dan tepat waktu

11. Bertanggungjawab terhadap tugas, fungsi dan pernanannya dalam kelompoknya

12. Selalu berpartisipasi aktiv dalam kegiatan kelompok

13. Mampu bekerja sama dengan anggota kelompoknya, dan teman-temannya

14. Antusias dalam mengerjakan tugas-tugasnya

15. Selalu berkoordinasi dengan teman atau kelompoknya sebelum melakukan sesuatu pekerjaan dalam penyelesaian tugas-tugasnya.

16. Tidak menjiplak, menyontek, dan meniru hasil tugas-tugas orang lain atau kelompok lain baik dalam satu kelas maupun kelas lain

17. Siap menerima perintah

18. Memiliki rasa toleransi terhadap teman-temannya

19. Selalu menyertakan sumber informasi dalam pengerjaan tugas-tugasnya

20. Mampu menampilkan hasil tugas-tugasnya dengan baik di depan guru dan temantemannya. 
Aktivitas-aktivitas tersebut didapatkan dalam penerapan penilaian keterampilan mata pelajaran PPKn. Sehingga dengan rutinitas aktivitas tersebut akan menjadi kebiasaan peserta didik dalam kehidupan sehari-harinya. Dengan demikian sikap tanggungjawabpun secara perlahan akan terbentuk pada diri masing-masing peserta didik. Hal ini akan menjadi modal yang sangat besar bagi mereka ketika mereka berada dalam lingkungan masyarakat, bangsa dan Negara. Maka sikap tanggungjawab ini akan melekat pada mereka, dan tebentuklah sikap tanggungjawab warga negaranya dengan baik.

Berangkat dari pemaparan masalah-masalah di atas, penulis merasa tertarik untuk mengetahui lebih jauh mengenai "Seberapa Besar Pengaruh Penilaian Keterampilan Mata Pelajaran PPKn Dalam Kurikulum 2013 Terhadap Pembinaan Tanggungjawab Warga Negara (Civic Responsibility) Pada Peserta Didik SMK Negeri Se-Kota Bandung?”

\section{Rumusan Masalah}

1. Seberapa besar pengaruh perencanaan guru dalam menerapkan penilaian keterampilan mata pelajaran PPKn dalam kurikulum 2013 terhadap pembinaan tanggungjawab warga negara (Civic Responsibility) pada peserta didik SMK Negeri Se-Kota Bandung?

2. Seberapa besar pengaruh pelaksanaan penilaian keterampilan mata pelajaran PPKn dalam kurikulum 2013 terhadap pembinaan tanggungjawab warga negara (Civic Responsibility) pada peserta didik SMK Negeri Se-Kota Bandung?

\section{Hipotesis}

Berdasarkan paparan teori-teori di atas, maka dapat diajukan hipotesis:

1. Terdapat pengaruh perencanaan guru dalam menerapkan penilaian keterampilan mata pelajaran PPKn dalam kurikulum 2013 terhadap pembentukan sikap tanggungjawab warga negara (Civic Responsibility) pada peserta didik SMK Se-Kota Bandung

2. Terdapat pengaruh pelaksanaan penilaian keterampilan mata pelajaran PPKn dalam kurikulum 2013 terhadap pembentukan sikap tanggunggungjawab warga negara (Civic Responsibility) pada peserta didik SMK Se-Kota Bandung.

\section{METODOLOGI PENELITIAN}

Penelitian ini menggunakan metode survei dengan pendekatan kuantitatif, dengan mengembangkan dua variabel independen (Perencanaan penilaian keterampilan mata pelajaran PPKn kurikulum 2013 dan Pelaksanaan penilaian keterampilan mata pelajaran 
PPKn kurikulum 2013), dan satu variabel dependen (Pembinaan tanggungjawab warga negara (civic responsibility) pada peserta didik).

Penelitian ini dilakukan di SMK Negeri Se-Kota Bandung. Adapun subyek penelitiannya adalah Peserta didik kelas XI SMK Negeri Se-Kota Bandung dengan populasi sebanyak 16 SMK Negeri dengan jumlah peserta didik sebanyak 2380 orang peserta didik dan diambil 5 SMK sebagai sampel dengan jumlah sampel 336peserta didik.

Untuk menentukan jumlah sampel penulis menggunakan dua tahapan yaitu : 1) mencari sampel dari total populasi dengan menggunakan teknik purposive sampling. 2) mencari jumlah sampel untuk masing-masing SMK dengan menggunakan teknik random sampling sehingga diperoleh 336 sampel sebagai responden.

Pengumpulan data primer dalam penelitian ini menggunakan angket yang berisikan pernyataan-pernyataan dengan lima alternatif jawaban yaitu tidak pernah, jarang, kadangkadang, sering, selalu (skala likert).

Untuk menganalisis pengaruh kausalitas antara variabel independen terhadap variabel dependen, dalam penelitian ini penulis membedakan dua kategori yaitu analisis deskriptif dan analisis hipotesis. Analisis deskriptif menggunakan rumus rata-rata (Weighted Means Scored) dari Furqon (2011, hlm. 42).Sedangkan analisis hipotesis menggunakan rumus regresi dan korelasi (Hartono, 2008, hlm. 178)

\section{HASIL DAN PEMBAHASAN}

Has il

Hasil analisis deskriptif menunjukkan bahwa secara umum variabel $Y$ (Tanggungjawab warga negara pada peserta didik) di kategorikan cukup, dengan skor ratarata sebesar 3,14. Untuk variabel $\mathrm{X}_{1}$ (Perencanaan penilaian keterampilan mata pelajaran PPKn) di kategorikan cukup, dengan skor rata-rata sebesar 3,17. Sedangkan variabel $\mathrm{X}_{2}$ (Pelaksanaan penilaian keterampilan mata pelajaran PPKn) di kategorikan cukup, dengan skor rata-rata sebesar 3,40 .

Untuk lebih jelasnya dapat dilihat dalam grafik di bawah ini

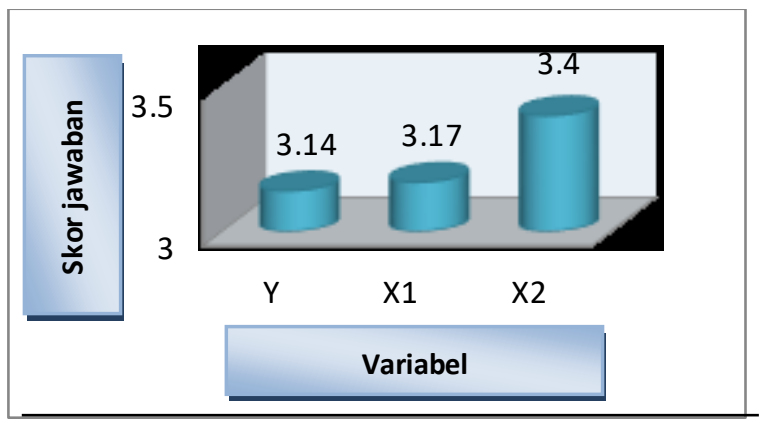




\section{Gambar 1.}

\section{Rata-Rata Setiap Variabel}

Selanjutnya, hasil analisis koefisien korelasi ditemukan bahwa secara parsial pengaruh variabel perencanaan penilaian keterampilana mata pelajaran PPKn terhadap pembinaan tanggungjawab warga negara sebesar 0,136 dan pengaruh variabel pelaksanaan penilaian keterampilan mata pelajaran PPKn sebesar 0,137. Sedangkan secara simultan pengaruh variabel perencanaan dan pelaksanaan penilaian keterampilan mata pelajaran PPKn sebesar 0,214 .

Konstanta untuk masing-masing korelasi tersebut selanjutnya ditransformasi ke dalam persamaan regresi yaitu: $\mathrm{Y}=0,214+0,136 \mathrm{X}_{1}+0,137 \mathrm{X}_{2}$

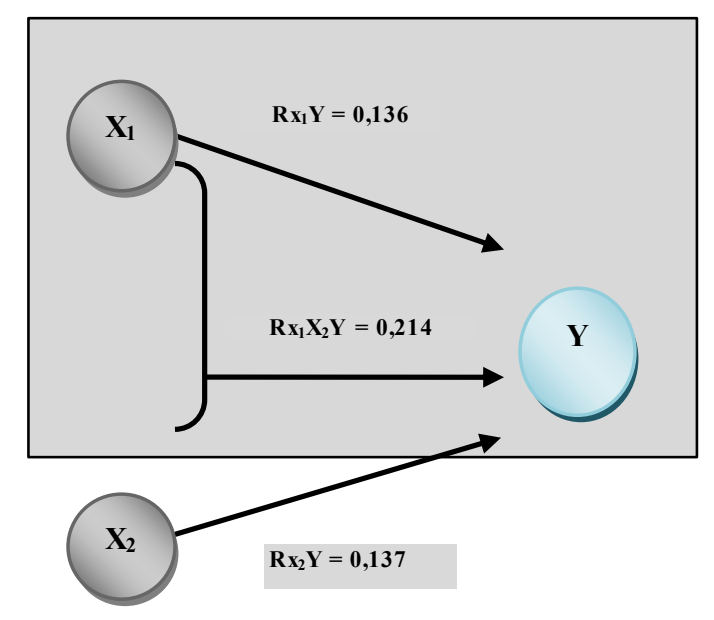

\section{Gambar 2}

\section{Struktur Pengaruh $X_{1}, X_{2}$ Terhadap $Y$}

\section{Pembahasan}

Penilaian keterampilan disebut juga dengan istilah penilaian kinerja, karena didalamnya menilai aktivitas kegiatan-kegiatan peserta didik dalam mengerjakan tugastugasnya baik tugas praktek, proyek, dan portofolio. Penilaian keterampilan atau penilaian kinerja adalah penilaian yang mengedepankan pada aspek karya atau hasil yang telah ditargetkan, hal ini sesuai dengan pendapat Cushway B. (2002: 1998) yang menyatakan bahwa penilaian kinerja adalah menilai bagaimana seseorang telah bekerja dibandingkan dengan target yang telah ditentukan. Hal ini mengandung pengertian bahwa penilaian keterampilan merupakan penilaian yang dilakukan dengan selalu memperhatikan proses dibandingkan dengan hasil. 
Pembentukan sikap tanggungjawab warga negara merupakan salah satu visi dan misi dari mata pelajaran PPKn. Di mana pada aspek penanaman sikap tanggungjawab warga negara ini tergolong kedalam jenis civic disposition atau watak kewarganegaraan. Sikap tanggungjawab merupakan salah satu watak warga negara yang baik yang harus dikembangkan dan ditanamkan sejak dini kepada para peserta didik dengan berbagai cara yang mampu dilakukan oleh para guru. Salah satunya dilakukan pada aspek penilaian. Sikap tanggungjawab atau civic responsibility merupakan bagian dari civic disposition yang harus dikembangkan dan dimiliki oleh para peserta didik sebagai generasi penurus untuk menghasilkan warga negara yang baik.

Secara konseptual civic disposition meliputi sejumlah karakteristik kepribadian, yakni: "Civility (respect and civil discourse), individual responsibility, self discipline, civicmindedness, open-mindedness (openness, skepticism, recognition of ambiguity), compromise (conflict of principles, compassion, enerosity, and loyalty to the nation and its principles" (quigly, Buchanan, dan Bahmueller, 1991 , hlm. 13-14). Maksud semua itu adalah kesopanan yang mencakup penghormatan dan interaksi manusiawi, tanggung jawab individual, disiplin diri, kepedulian terhadap masyarakat, keterbukaan pikiran yang mencakup keterbukaan, skeptisme, pengenalan terhadap kemenduaan, sikap kompromi yang mencakup prinsipprinsip konflik dan batas-batas kompromi, toleransi pada keragaman, kesabaran dan keajekan, keharuan, kemurahan hati, dan kesetiaan terhadap bangsa dan segala prinsipnya.

Branson (1999, hlm. 23) menegaskan bahwa civic disposition mengisyaratkan pada karakter publik maupun privat yan penting bagi pemeliharaan dan pengembangan demokrasi konstitusional. Watak-watak kewarganegaraan sebagaimana kecakapan kewarganegaraan, berkembang secara perlahan sebagai akibat dari apa yang telah dipelajari dan dialami oleh seseorang di rumah, sekolah, komunitas, dan organisasi-organisasi civil society. Karakter privat seperti tanggung jawab moral, disiplin diri dan penghargaan terhadap harkat dan martabat manusia dari setiap individu adalah wajib. Karakter publik juga tidak kalah penting. Kepedulian sebagai warga negara, kesopanan, mengindahkan aturan main (rule of law), berpikir kritis, dan kemauan untuk didengar, bernegoisasi dan berkompromi merupakan karakter yang sangat diperlukan agar demokrasi berjalan dengan sukses.

Selanjutnya Branson (1999, hlm. 23-25) menjelaskan secara singkat karakter publik dan privat yang dideskripsikan sebagai berikut: (1) Menjadi anggota masyarakat yang independen; (2) Memenuhi tanggung jawab personal kewarganegaraan di bidang ekonomi dan politik; (3) Menghormati hak-hak orang lain; (4) Berpartisipasi dalam urusan-urusan 
kewarganegaraan secara efektif dan bijaksana; (5) Mengembangkan berfungsinya demokrasi konstitusional secara sehat.

Dalam kurikulum 2013, watak atau karakter warga Negara yang harus dikembangkan adalah terletak pada aspek penanaman sikap, kepribadian, dan karakter warga Negara. Salah satunya adalah karakter warga Negara yang bertanggungjawab (Civic Responsibility). Pembentukan tanggungjawab warga Negara dalam kurikulum 2013, merupakan salah satu bagian dari tujuan kurikulum 2013. Tanggungjawab ini meliputi tanggungjawab terhadap diri sendiri, tanggungjawab terhadap keluarga, tanggungjawab terhadap masyarakat, tanggungjawab tehadap bangsa dan Negara, tanggungjawab terhadap Tuhan.

Pembentukan tanggungjawab warga Negara tersebut salah satunya melalui aspek penilaian keterampilan dalam kurikulum 2013. Penilaian keterampilan dikenal dengan aspek penilaian kinerja. Karena penilaian ini lebih menekankan pada aspek kinerja para peserta didik dan keterampilan peserta didik dalam berkomunikasi, bersosialisasi, dan terampil mempertanggungjawabkan apa yang telah dikerjakannya. Hal ini akan melath para peserta didik untuk senantiasa memiliki jiwa dan sikap tanggungjawab terhadap kinerjanya dalam menyelesaikan tugas-tugasnya.

Sikap tanggungjawab yang muncul dari hasil perapan penilaian keterampilan mata pelajaran PPKn dalam kurikulum 2013 ini terdiri dari:

1. Taat dan patuh pada ajaran agama yang dianutnya

2. Datang dan pulang sekolah tepat waktu

3. Selalu mentaati segala peraturan sekolah, rumah, masyarakat, dan negaranya

4. Membantu temannya yang kesusahan

5. Taat dan hormat pada guru, dan orang tua

6. Belajar dengan baik dan tidak pernah bolos sekolah

7. Selalu mengerjakan tugas sekolah dengan tepat waktu

8. Aktiv dalam kegiatan diskusi kelompok

9. Menghormati dan menghargai pendapat orang lain dan tidak pernah memaksakan kehendaknya kepada orang lain

10. Mengerjakan tugas-tugasnya dengan teliti, cermat, kreatif dan tepat waktu

11. Bertanggungjawab terhadap tugas, fungsi dan pernanannya dalam kelompoknya

12. Selalu berpartisipasi aktiv dalam kegiatan kelompok

13. Mampu bekerja sama dengan anggota kelompoknya, dan teman-temannya

14. Antusias dalam mengerjakan tugas-tugasnya 
15. Selalu berkoordinasi dengan teman atau kelompoknya sebelum melakukan sesuatu pekerjaan dalam penyelesaian tugas-tugasnya.

16. Tidak menjiplak, menyontek, dan meniru hasil tugas-tugas orang lain atau kelompok lain baik dalam satu kelas maupun kelas lain

17. Siap menerima perintah

18. Memiliki rasa toleransi terhadap teman-temannya

19. Selalu menyertakan sumber informasi dalam pengerjaan tugas-tugasnya

20. Mampu menampilkan hasil tugas-tugasnya dengan baik di depan guru dan temantemannya.

Aktivitas-aktivitas tersebut didapatkan berdasarkan hasil temuan dalam penelitian ini. Dan sikap-sikap tersebut didapatkan salah satunya dari hasil penerapan penilaian keterampilan mata pelajaran PPKn, sehingga dengan kata lain penilaian keterampilan mata pelajaran PPKn dalam kurikulum 20013 melatih para peserta didik untuk melakukan kebiasan-kebiasaan tersebut di atas dalam kehidupan sehari-harinya. Dengan demikian sikap tanggungjawabpun secara perlahan akan terbentuk pada diri masing-masing peserta didik.

Penilaian keterampilan sangat efektif dïmpelementasikan pada tingkat SMK, karena pada dasarnya SMK merupakan tingkat pendidikan yang mengedepankan aspek keterampilan (skill) yang dilatih melalui berbagi tugas-tugas praktek, simulasi, dan pelatihan-pelatihan. Sehingga SMK bisa dijadikan salah satu percontohan pengimplementasian penilaian keterampilan. Selian itu kita tau bahwa SMK merupakan tingkat satuan pendidikan yang mengedapankan aspek keterampilan yang utama (vocasional education).

Selanjutnya untuk perencanaan penilaian keterampilan mata pelajaran PPKn merupakan hal yang penting sebelum dilaksanakan penilaian keterampilan oleh guru. Perencanaan menurut Suandy E. (2001, hlm. 2) Secara umum perencanaan merupakan proses penentuan tujuan organisasi (perusahaan) dan kemudian menyajikan (mengartikulasikan) dengan jelas strategi-strategi (program), taktik-taktik (tata cara pelaksanaan program) dan operasi (tindakan) yang diperlukan untuk mencapai tujuan perusahaan secara menyeluruh. Usman H. (2008) juga berpendapat bahwa perencanaan adalah perhitungan dan penentuan tentang sesuatu yang akan dijalankan dalam rangka mencapai tujuan tertentu, siapa yang melakukan, bilamana, di mana, dan bagaimana cara melakukannya.

Manfaat perencanaan penilaian keterampilan sebagaimana dikemukakan oleh Usman H. (2008) yaitu sebagai berikut: 
1. Membantu manajemen untuk menyesuaikan diri dengan perubahan-perubahan lingkungan,

2. Membantu dalam kristalisasi persesuaian dalam masalah-masalah utama,

3. Memungkinkan manajer memahami keseluruhan gambaran operasi lebih jelas,

4. Pemilihan berbagai alternatif terbaik,

5. Standar pelaksanaan dan pengawasan,

6. Penyusunan skala prioritas, baik sasaran maupun kegiatan,

7. Menghemat pemanfaatan sumber daya organisasi,

8. Alat memudahkan dalam berkoordinasi dengan pihak terkait,

9. Membuat tujuan lebih khusus, terperinci dan lebih mudah dipahami,

10. Meminimumkan pekerjaan yang tidak pasti, dan

11. Menghemat waktu, usaha dan dana.

Penilaian merupakan salah satu bentuk evaluasi yang dilakukan dengan proses dan tahapan-tahapan tertentu. Aspek penilaian merupakan hal tidak bisa dipisahkan dalam dunia pendidikan. Dalam kurikulum 2013 aspek penilaian merupakan salah masalah yang dihadapi oleh guru-guru disekolah yang menjadi sekolah percontohan implementasi kurikulum 2013. Penilaian dalam kurikulum 2013 terdirid dari 3 jenis penilaian yaitu penilaian sikap, penilaian pengetahuan, dan penilaian keterampilan. Dalam konsep ini penilaian keterampilan merupakan salah satu bentuk penilaian yang sangat autentik, dan factual, karena penilaian keterampilan merupakan salah penilaian yang dikenal dengan istilah penilaian kinerja.

Berdasarkan hasil penelitian dan pemaparan data di atas, untuk variabel perencanaan guru dalam menerapkan penilaian keterampilan mata pelajaran PPKn dalam kurikulum 2013 ini telah memberikan pengaruh yang sangat signitifikan terhadap pembentukan sikap tanggungjawab warga negara pada peserta didik. Hal ini menandakan bahwa perencanaan guru dalam menerapkan penilaian keterampilan mata pelajaran PPKn dalam kurikulum 2013 sangat memberikan pengaruh yang sangat signifikan terhadap pembentukan sikap tanggungjawab warga negara pada peserta didik SMK Negeri Se-Kota Bandung.

Hal ini terjadi karena semua indicator dalam variabel ini telah dijalankan oleh guru mata pelajaran PPKn sebelum menerapkan penilaian keterampilan mata pelajaran PPKn. Adapun indicator yang dimaksud yaitu:

1. Teori, prinsip, dan prosedur penilaian keterampilan

2. Mengkaji isi silabus dan materi pembelajaran

3. Memilih teknik atau jenis penilaian keterampilan 
4. Perumusan kisi-kisi penilaian

5. Pembuatan tugas praktek, proyek, dan portofolio

6. Pengalokasian waktu pelaksanaan penilaian keterampilan

Dari semua indicator yang dirumuskan sebagai perencanaan guru dalam melaksanakan penilaian keterampilan mata pelajaran PPKn kurikulum 2013, semua indicator tersebut sudah dijalankan oleh guru dan diterapkan oleh semua guru mata pelajaran PPKn di sekolah yang dijadikan sampel penelitian. Hal tersebut didasarkan pada hasil temuan data yang telah diolah dan dipaparkan di atas.

Ketentuan-ketentuan tersebut kemudian dijabarkan oleh para guru mata pelajaran PPKn untuk membuat sebuah rancangan penilaian keterampilan, berupa pemberian penugasan praktek, prokyek, dan portofolio. Masing-masing rancangan penugasan telah dibuat sedemikian rupa untuk memudahkan para peserta didik dalam menjalankan penugasan-penugasan praktek, proyek dan portofolio tersebut. Adapun tahapan yang dilalui oleh guru dalam mempersiapkan rancangan penilaian keterampilan mata pelajaran PPKn dalam Buku Guru PPKn Kelas XI (2013) diantaranya:

1. Guru menyampaikan tentang teori, landasan, prinsip, dan tujuan penilaian keterampilan kepada para peserta didik.

2. Guru menyesuaikan jenis dan rancangan penilaian keterampilan dengan materi pelajaran yang dipelajari peserta didik

3. Membuat dan memperlihatkan serta menjelasakan instrument, rubric atau pedoman penilaian keterampilan

4. Membuat dan menjelaskan kisi-kisi penugasan penilaian keterampilan berupa penugasan praktek, proyek, dan portofolio.

5. Menentukan jenis-jenis penugasan praktek, proyek, dan portofolio sesuai dengan materi pelajaran dan sesuai dengan kemampuan peserta didik.

6. Menjelaskan tahapan-tahapan atau langkah-langkah serta teknik pengerjaan penugasan praktek, proyek, dan portofolio.

7. Menentukan batas waktu pengerjaan penugasan praktek, proyek, dan portfolio.

Langkah-langkah tersebut telah ditempuh oleh para guru mata pelajaran PPKn sebelum menerapkan penilaian keterampilan, yang telah dibuktikan dengan hasil data yang diperoleh dari para peserta didik melalui angket penelitian. 
Dalam penilaian mata pelajaran PPKn 60\% lebih mengedepankan pada aspek penilaian sikap, 20\% pada aspek pengetahuan, dan 20\% pada aspek ketrampilan. Hal ini bertujuan agar penanaman sikaplah yang paling utama di dalam pembelajaran PPKn, sikap yang baik, ahlak yang mulia, demokratis, mandiri, tanggungjawab merupakan salah satu indicator dari tujuan pembelajaran PPKn. Sebagaimana dinyatakan oleh Branson (1999, hlm. 7) tujuan civic education adalah partisipasi yang bermutu dan bertanggung jawab dalam kehidupan politik dan masyarakat baik tingkat lokal, negara bagian, maupun nasional.

Jenis penilaian keterampilan yang digunakan untuk mengukur kompetensi keterampilan peserta didik yaitu dengan cara pemberian tugas yang terdiri dari penugasan praktek, proyek, dan portofolio. Adapun langkah-langkah pelaksanaan penilaian keterampilan mata pelajaran PPKn sebagai tercantum dalam Buku Guru PPKn Kelas XI (2013) ternyata sudah ditrapkan oleh guru mata pelaajran PPKn di SMK Negeri Se-Kota Bandung.

Untuk variabel $\mathrm{X}_{2}$ tersebut secara individual telah diuji pengaruhnya dalam uji hipotesis secara individu yaitu sebesar $1,9 \%$ telah memberikan pengaruh terhadap pembinaan tanggungjawab warga negara. Hal tersebut dapat dikatakan bahwa pelaksanaan penilaian keterampilan memberikan pengaruh yang baik terhadap pembinaan, penanaman, dan pembinaan tanggungjawab warga negara pada peserta didik SMK Negeri Se-Kota Bandung.

Melalui pelaksanaan penilaian keterampilan peserta didik dibiasakan untuk mengerjakan tugas-tugas yang diterimana untuk dikerjakan secara maksimal, tepat waktu, dan harus mampu menampilkan hasil pengerjaan tugas-tugasnya dihadapan teman-temanya dan gurunya. Proses pembiasaan inilah yang akan melatih dan membina tanggungjawab peserta didik terhadap tugas-tugasnya, dan atas apa yang telah dikerjakannya.

\section{Temuan Penelitian}

Berdasarkan hasil penelitian dalam di dapat bahwa factor lain yang ternyata memberikan pengaruh terhadap pembentukan sikap tanggungjawab warga negara pada peserta didik SMK ini pada dasarnya adalah akvitas-akvitas mata pelajaran produktif. Setiap mata pelajaran produktif atau mata pelajaran kelompok $\mathrm{C}$ pada jenjang SMK, mengharuskan adanya praktek. Dari praktek-praktek inilah yang ternyata memberikan sumbangan besar terhadap pembentukan sikap tanggungjawab ini. Hal ini sesuai dengan pendapat Branson (1999, hlm. 23-25), yang menyatakan bahwa Kesadaran secara pribadi untuk bertanggungjawab sesuai ketentuan, bukan karena keterpaksaan atau pengawasan dari luar, menerima tanggungjawab akan konsekuensi dan tindakan yang diperbuat dan memenuhi kewajiban moral dan legal sebagai anggota masyarakat demokratis. 
Sikap dan karakter tanggungjawab peserta didik, tidak muncul begitu saja, melainkan harus melalui serangkaian latihan atau pembinaanmelalui pembiasaan mengerjakan tugastugas baik tugas individu, maupun tugas kelompoknya. Sehingga mereka akan menyadari akan pentingnya jiwa dan sikap tanggungjawab dalam menyelesaikan tugas-tugasnya, baik tugas individu maupun kelompoknya. Dengan demikian sikap tanggungjawab akan terbentuk dan tertanam dalam diri peserta didik melalui pembinaan dan pembiasaan pengerjaan tugastugasnya dengan baik dan benar.

Praktek-praktek mata pelajaran produktif telah membantu menumbuhkan jiwa dan sikap tanggungjawab terhadap tugas-tugas yang diberikan guru kepadanya. Dan selalu dikerjakan dengan penuh keiklasan tanpa ada paksaan, hanya semata-mata menyadari bahwa tugas tersebut sebagian dari penilaian untuk mendapatkan nilai yang mereka inginkan.

Salah satu contoh yang mencolok yang peneliti temukan adalah di SMK Negeri 10 yang merupakan bidang keahlian kesenian. Semua siswa diajarkan teori menari, drama, musik, dan lain-lain. Dan semua siswa harus mahir pula untuk mempraktekannya dihadapan teman-temannya bahkan harus dijadikan sebagai pertujukan atau konser. Hal ini telah melatih mereka untuk belajar bertanggungjawab terhadap peran dan tugas mereka masing-masing untuk menyelesaikan tugas-tugas mereka masing-masing baik secara kelompok atau secara individu.

Widoyoko (2014, hlm. 46) menyatakan bahwa penilaian keterampilan atau psikomotor merupakan kemampuan bertindak setelah seseorang menerima pengalaman belajar tertentu.Pendapat tersebut jelas bahwa penilaian keterampilan merupakan penilaian penerapan hasil apa yang dipelajari oleh para peserta didik yang dapat dilakukan dalam kehidupan sehari-harinya secara rutin sebagai satu kebiasaan khususnya dalam proses mempraktekan keterampilan warga negara yang bertanggungjawab, sehingga dengan rutinitas aktivitas tersebut akan menjadi kebiasaan peserta didik dalam kehidupan sehari-harinya.

Berdasarkan data hasil penelitian, penilaian keterampilan mata pelajaran PPKn kurikulum 2013 ini memberikan pengaruh secara simultan tehadap pembentukan sikap tanggungjawab warga negara pada peserta didik yaitu sebesar 0,248. Artinya memberikan pengaruh penilaian keterampilan mata pelajaran PPKn terhadap pembentukan sikap tanggungjawab warga negara pada peserta didik pengaruhnya rendah atau berkorelasi rendah.

Hal ini disebabkan karena SMK merupakan sekolah kejuruan yang mengedepankan keahlian, dan keterampilan melalui pelatihan keterampilan berdasarkan bidang keahliannya masing-masing. Sehingga praktek pada SMK sangat diutamakan untuk melatih keterampilan para peserta didiknya, dan itulah sebabnya SMK disebut sebagai sekolah pengembangan 
keterampilan atau vocational skill. Sehingga penilaian keterampilan di SMK memberikan pengaruh yang rendah terhadap pembentukan sikap tanggungjawab warga negara, karena sikap tanggungjawab ini sudah dibentuk dan dilath melalui kegiatan praktek-praktek dari masing-masing mata pelajaran produktif atau kelompok mata pelajaran $\mathrm{C}$.

Namun tetap penilaian keterampilan mata pelajaran PPKn telah memberikan pengaruh yang signifikan terhadap pembentukan sikap tanggungjawab warga negara pada peserta didik, dan hal ini dibuktikan dengan hasil penelitin ini. Artinya tetap penilaian keterampilan mata pelajaran PPKn dalam kurikulum 2013 telah memberikan pengaruh terhadap pembinaan tanggungjawab warga negara pada peserta didik, dan artinya ini sudah mengarah kepada pencapaian tujuan pendidikan nasional. Hal ini sesuai dengan UndangUndang Sisdiknas No. 20, Tahun 2003. Pasal 3 menyebutkan,Pendidikan nasional berfungsi mengembangkan kemampuan dan membentuk watak serta peradaban bangsa yang bermartabat dalam rangka mencerdaskan kehidupan bangsa, bertujuan untuk berkembangnya potensi peserta didik agar menjadi manusia yang beriman dan bertakwa kepada Tuhan Yang Maha Esa, berakhlak mulia, sehat, berilmu, cakap, kreatif, mandiri, dan menjadi warga negara yang demokratis serta bertanggung jawab."

Hal ini membuktikan bahwa penilaian keterampilan dalam kurikulum 2013 memang layak untuk diterapkan dan dikembangkan guna menunjang pencapaian tujuan dari system pendidikan nasional khususnya dalam mata pelajaran PPKn, yang salah satunya adalah membina pribadi yang bertanggungjawab dan demokratis.

\section{KESIMPULAN}

\section{Kesimpulan}

1) Perencanaan guru dalam melaksanakan penilaian keterampilan mata pelajaran PPKn dalam kurikulum 2013 telah memberikan pengaruh yang signifikan terhadap pembinaan tanggungjawab warga negara (civic responsibility) pada peserta didik SMK Negeri SeKota Bandung sebesar 0,136. Hal tersebut mengandung pengertian bahwa semakin sering guru melakukan perencanaan penilaian keterampilan dengan matang, maka tanggungjawab warga negara akan semakin tumbuh dan berkembang dengan baik pada diri peserta didik.

2) Pelaksanaan penilaian keterampilan mata pelajaran PPKn dalam kurikulum 2013 telah memberikan pengaruh yang signifikan terhadap pembembinaan tanggungjawab warga negara (civic responsibility) pada peserta didik SMK Negeri Se-Kota Bandung sebesar 0,137. Artinya semakin sering guru melaksanakan penilaian keterampilan melalui 
perencanaan yang matang, prosedur yang benar, maka semakin besar pula pengaruhnya terhadap pembinaan tanggungjawab warga negara (civic responsibility) pada peserta didik.

\section{DAFTAR RUJUKAN}

Bachri, S. Bachtiar. (2010). Impelementasi pengembangan Content Curriculum dalam proses perencanaan pembelajaran. Jurnal Teknologi Pendidikan, 10 (2), 1-11.

Bahrul, H. (2014) Penilaian Kelas (Classroom Assessment) dalam Penerapan Standard Kompetensi. Jurnal Pendidikan Penabur. 03 (12), 110.

Barry Cushway (2002: 1998) Kinerja. http://id.wikipedia.org/wiki/ diunduh tanggal 20 April 2015.

Borhan, L. (1998), Penilaian Autentik Pada Kurikulum 2013 Revisi Prodi Pendidikan Matematika Jurusan Pendidikan Matematika Dan Ilmu Pengetahuan Alam Fakultas Tarbiyah Universitas Islam Negeri Sunan Ampel Surabaya 2013. Jurnal Pendidikan Universitas Negeri Sunan Ampel Surabaya 2013.https://www.academia.edu/7233687.

BSNP. (2007). Panduan Penilaian Kelompok Mata Pelajaran Ilmu Pengetahuan Dan Teknologi. http:/dikmenum.go.id/dataapp/kurikulum/3.\%20PANDUAN\%20 PENILAIAN\%20KEL\%205\%20MAPEL/C_Panduan_Kel_Mapel_Ipteks.pdf (diakses tanggal 15 November 2014).

Branson, M.S. (1998). The Role of Civic Education.Calabasas : Center for Civic Education.

Branson, M.S. (1999). Making the Case for Civic Education: Where We Stand at the End of the 20th Centure.Washington: CCE.

Budimansyah, D dan Suryadi, K. (2008). PKn dan Masyarakat Multikultural. Bandung. Universitas Pendidikan Indonesia

Budimansyah \& Winataputra. (2007). Civic Education Konteks, Landasan Bahan Ajar dan Kultur Kelas. Bandung : Program Studi Pendidikan Kewarganegaraan SPS UPI.

Buku Guru PPKn Kelas XI (2014). Buku Pegangan Guru Pendidikan Kewarganegaraan Kelas XI SMA/SMK. Jakarta : Depdiknas.

Center for Indonesia Civic Education/CICED (1999) .Democratic Citizens in a Civic society: Report of the Conference on Civic Education for Civic Society, Bandung : CICED.

Goudarz Alibakhshi* \& Hassan Sharakipour. (2014) The Effect of Self-Assessment on EFL Learners' Receptive Skills (Kesan Penilaian Kendiri terhadap Kemahiran Reseptif dalam Kalangan Pelajar Bahasa Inggeris sebagai Bahasa Kedua (ELF). Jurnal Pendidikan Malaysia 39 (1) , 9-17.

Furqon. (2011). Statistik Terapan untuk Penelitian. Bandung: Alfabeta. 
Hartono.(2008). Statistik Untuk Penelitian.Yogyakarta : Pustaka Pelajar.

Husaini Usman (2008). Manajemen. Jakarta: Bumi Aksara

Komang, D.M., Made, Y., \& I Gusti, K.A.S. (2013). Kontribusi kompetensi profesional, kompetensi pedagogik, dan kepuasan kerja terhadap kinerja guru PKn pada SMP Negeri se-Kabupeten Tabanan.e-Journal. Program Pascasarjana Universitas Pendidikan Ganesha, (4), 1-20.

Maftuh, B dan Sapriya. (2005). Pembelajaran Pendidikan Kewarganegaraan Melalui Pemetaan Konsep. Jurnal Civicus 1, (5), 319-321.

Peraturan Menteri Pendidikan dan Kebudayaan Nomor. 104 tahun 2014 tentang Standar Penilaian Pendidikan. Jakarta: Kemendikbud.

Peraturan Pendidikan Nasional 20 Tahun 2007 tentang Standar Penilaian Pendidikan. Jakarta: Kemendikbud.

Sapriya (2001). http://www.gudangmateri.com/2011/05/ tujuan pendidikan kewarganegaraan .html. diunduh tanggal 10 April 2015.

Wagiran, dkk. (2013). Determinan kinerja guru SMK bidang keahlian teknik mesin. Jurnal. Penilaian Evaluasi Pendidikan, 17 (1), 148-171 